\title{
Tuzlu-Alkali Meralarda Yaygın Olarak Yetişen Çorak Çimi (Puccinellia distans) ve Sahil Ayrığı (Aeluropus littoralis) Bitkilerinin Farklı Gelişme Dönemlerindeki Besin içeriklerinin Belirlenmesi
}

\author{
Süleyman Temel \\ Iğdır Üniversitesi, Ziraat Fakültesi, Tarla Bitkileri Bölümü, Iğdır \\ Geliş tarihi (Received): 03.07.2018 \\ Kabul tarihi (Accepted): 11.08.2018
}

\begin{abstract}
Anahtar kelimeler:
Çorak çimi, çorak meralar, fenolojik dönemler, sahil ayrığı, yem kalitesi

Özet. Bitki yetiştiriciliği ve çeşitliliğini kısıtlayan özellikle iklim ve topraktan kaynaklanan stres koşulları bitkilerde önemli verim ve kalite kayıplarına neden olabilmektedir. Oysa ekstrem ekolojik koşullara uyum sağlayabilen halofit türler üretim güçlerini devam ettirerek, yeter miktar ve kalitede yem materyali üretebilmektedir. Bu araştırma, hiçbir kültür bitkisinin yetiştirilemediği aşırı tuzlu-alkali otlak alanlarında yaygın olarak yetişen halofit Puccinellia distans ve Aeluropus littoralis türlerinin farklı gelişme dönemlerinde sahip oldukları besin değerlerini belirlemek ve incelenen kalite özellikleri açısından ruminantların beslenmesinde yem kaynağı olarak değerlendirilip değerlendirilemeyeceğini ortaya koymak amacıyla yürütülmüştür. Bu amaçla vejetatif, çiçeklenme ve tohum olgunlaştırma döneminde mevcut türlerin sahip oldukları ham protein, nötr çözücülerde çözünemeyen lif, asit çözücülerde çözünemeyen lif, kuru madde sindirilebilirliği, sindirilebilir enerji, metabolik enerji ve nispi yem değerleri tespit edilmiştir. Araştırma lğdır coğrafyasında iki yıl süre ile (2015-2016) korunan 4 dekarlık bir alanda tesadüf bloklarında bölünmüş parseller deneme desenine göre 3 tekerrürlü olarak yürütülmüştür. Araştırma sonucunda incelenen tüm parametrelerin türlere (nötr çözücülerde çözünemeyen lif hariç), fenolojik dönemlere ve yıllara bağlı olarak önemli farklılıklar gösterdiği ortaya çıkmıştır. Sonuç olarak, A. littoralis gelişme dönemlerine bağlı olarak $P$. distans türüne göre daha yüksek kalitede yem materyali sağlayabildiği ve tuzlu mera alanlarında otlayan ruminatlar için iyi bir alternatif yem kaynağı olabileceği ortaya konulmuştur.

*Sorumlu yazar

stemel33@hotmail.com
\end{abstract}

\section{Determination of Nutritional Contents at the Different Development Stages of Puccinellia distans and Aeluropus littoralis Commonly Growing in Saline-Alkaline Pastures}

\section{Keywords:}

Weeping alkaligrass, coast aeluropus, arid grazings, phenological stages, forage quality

\begin{abstract}
Stress conditions, especially due to climate and soil, which limit plant growing and diversity can cause important yield and quality losses in plants. However, halophytic species which can adapt to extreme ecological conditions can produce feed material at adequate amounts and quality by continuing to production potential. Our aim was to determine the forage qualities at different developmental stages of Puccinellia distans and Aeluropus littoralis, halofite species, which grow extensively in excessive-salted and alkaline pastures, and to reveal whether they can be evaluated as feed for ruminants in terms of the quality characteristics examined. For this purpose, crude protein, neutral detergent fibre, acid detergent fibre, dry matter digestibility, digestible energy, metabolic energy and relative feed values were determined at vegetative, flowering and seed maturation stages of the studied species. The experiment was established in randomized blocks with three replications according to the Split Parsel trial design on a protected 4 da pasture in Igdir conditions between the years of 2012-2013. As a result of the research, all the parameters examined showed significant differences depending on species (except for neutral detergent fibre), phenological stages and years. As a result, it was revealed that $A$. littoralis can be provided a higher quality feed than $P$. distans depending on development stages and, also be a good alternative source of fodder for ruminant in saline-grazing.
\end{abstract}




\section{GiRiş}

Kurak ve tuzdan etkilenmiş marjinal alanlarda farklı amaçlar (yağıı tohum, gıda, kaba yem, yakıt, lif, v.b.) için kullanım potansiyeline sahip pek çok halofit tür bulunmaktadır (Temel et al., 2015). Bu gibi marjinal alanlara uyum sağlamış kserofit ve halofit türler özellikle otsu türlerin dormant olduğu yaz ve sonbahar dönemlerinde üretim güçlerini devam ettirerek ruminantların beslenmesinde oluşan kaba yem ve besin açı̆̆ını kapatmada önemli rol oynamaktadırlar (Ahmadi et al., 2015; Temel et al., 2015). Çünkü tuza toleranslı yem bitkileri halofit olmayan türlerin yetişemediği kurak ve tuzlu alanlarda yüksek yenilebilen biomasa sahip yem üretebilmektedirler (ElShaer 2010). Nitekim halofit bitkilerin kurak ve yarı kurak bölgelerde koyun, keçi ve develerin beslenme programlarının önemli bir kısmını oluşturduğu rapor edilmiştir (Squires and Ayoub 1994; El Shaer 1997). Ancak maksimum hayvansal performansa ulaşmak ve çiftlik hayvanlarının dengeli bir şekilde beslenmesini sağlamak için otlayan hayvanların yem gereksinimlerinin ve otlatmaya başlama zamanlarının bilinmesi önemlilik arz etmektedir (Asaadi and Dadkhah 2010). Bunun için de mera alanlarında hayvanlar tarafından otlanan türlerin besin değerlerinin ortaya konulması gerekmektedir.

Kurak ve tuzlu otlak alanlarda yetişen halofit türler dahil mera yem bitkilerinin besin değerleri ve sindirilebilirlikleri; bitki türü, genotip, yetiştiği yerdeki iklim-toprak özellikleri, hastalık-zararlılar ve gelişme dönemine bağlı olarak farklıık göstermektedir (Arzani et al., 2001; El Shaer 2010; Temel 2015; Temel et al., 2015). Bu faktörler içerisinde fenolojik dönemler yem kalitesini belirleyen en önemli faktördür (Martiniello and Teixeira da Silva 2011; Ahmadi et al., 2005). Halofit türlerle yürütülen birçok çalışmada yem kalitesinin fenolojik dönemlere bağlı olarak değiştiği ortaya konulmuştur (Esfahan et al., 2010; Panahi et al., 2012; Valipoor Dastenai et al., 2012; Temel 2015; Temel et al., 2015). Yine baklagiller buğdaygillerden daha yüksek protein içeriğine (Norton 1982), tuza toleranslı bitki türleri ise genellikle yüksek protein, ancak düşük metabolik enerji ve yüksek tuz içeriğine sahiptirler (Norman et al., 2002). Besin profillerindeki farklııılardan dolayı tuza toleranslı bitkiler ancak diğer bitki türleri ile birlikte otlanırsa hayvansal üretimde iyileşme sağlanabilir. Nitekim Norman et al. (2002), tuza toleranslı buğdaygiller, baklagiller ve tuz çalılarının kombinasyonu ile yapılan bir otlatmanın hayvansal performansı ve besleme değerini iyileştirdiğini rapor etmişlerdir.

Puccinellia distans ve Aeluropus littoralis türleri kurak iklimlere ve aşırı tuzlu-alkali toprak koşullarına uyum sağlayabilen çok yıllık serin mevsim halofit buğdaygiller olup (Hughes 1972; Brotherson 1987; Scalia et al., 2009; Ali Ehsani et al., 2016), hem tuzlu topraklarda kolayca tesis oluşturabilmekte hem de bu alanların iyileştirilmesinde yaygın bir şekilde kullanılmaktadırlar (Hitchcock 1971; Tarasoff et al., 2007). Tuzlu çayır-mera alanları içerisinde yayıımış olan Puccinellia distans yılda hektara 4 ila 10 ton arasında kuru madde üretmekte (Warren et al., 1994) ve lezzetli olan bu tür (Shidaei and Namati 1978) genellikle koyunlar tarafından otlanmaktadır (Peng et al., 2004; Robinson et al., 2004). Yine vejetatif (rizomla) olarak üreyebilen Aeluropus littoralis türü (Gulzar and Khan 2001), gelişmekte olan ülkelerde yem kaynağı olarak yaygın kullanımının yanı sıra silaj olarak ve tuzlu alanların biyolojik ıslahında büyük bir kullanım potansiyeline sahiptir (Gulzar et al., 2003). Nitekim Rad et al. (2013), İran'ın tuzlu otlaklarında Aeluropus littoralis türünün dominant olduğunu ve çiftlik hayvanlarının yem gereksinimlerinin önemli bir kısmını karşıladığını rapor etmişlerdir. Sonuç olarak bu türler özellikle sonbahar ve kış dönemlerinde hayvanların gereksinim duydukları besinleri sağlamak için tuzlu otlak alanlarında kullanılmaktadırlar.

Kurak iklim özelliğine sahip Türkiye'nin kuzey doğusunda yer alan Iğdır coğrafyasında tarım alanlarının önemli bir kısmı çoraklıktan etkilenmiş ve üretim dışı kalmıştır (Özdoğan 1976; Temel ve Şimşek 2011). Başka kültür bitkilerinin yetiştirilemediği halomorfik topraklarda doğal olarak yetişebilen Aeluropus littoralis ve Puccinellia distans türleri, bölgede otlayan çiftlik hayvanları için önemli yem kaynakları olarak görülmüşlerdir. Ancak tuzlu-alkali otlak alanlarda yetişen ve çiftlik hayvanları tarafından tercih edilen bu türlerin gelişme dönemlerine göre yem kalitesinin belirlenmesine yönelik yeterli bir bilimsel çalışma bulunmamaktadır. Bu amaçla; Iğdır coğrafyasından toplanan Aeluropus littoralis ve Puccinellia distans türlerinin fenolojik dönemlere göre yem kalitesinin (HP, NDF, ADF KMS, ME, SE ve NYD) belirlenmesi amacıyla bu çalışma yürütülmüştür.

\section{MATERYAL VE METOT}

Bu çalışma 2015 ve 2016 yıllarında Türkiye'nin kuzey doğusunda yer alan Iğdır ilinin tuzlu-alkali otlak alanlarında iki yıl süre ile yürütülmüştür. Araştırmanın yürütüldüğü Iğdır ilinin 2015 ve 2016 ile uzun yıllar ortalamasına ait ortalama sıcaklık, nispi nem ve toplam yağış miktarları Çizelge $1^{\prime}$ de sunulmuştur. Çizelge 1 incelendiğinde denemenin yürütüldüğü yılların uzun 
Temel, Tuzlu-Alkali Meralarda Yaygın Olarak Yetişen Çorak Çimi (Puccinellia distans) ve Sahil Ayrığı (Aeluropus littoralis) Bitkilerinin Farklı Gelişme Dönemlerindeki Besin İçeriklerinin Belirlenmesi

yıllar ortalamasına göre daha sıcak ve nemli olduğu görülmektedir. Araştırmanın yürütüldüğü 2015 ve 2016 yıllarına ait iklim değerleri incelendiğinde ise 2015 yılı 2016 yılına göre daha yüksek sıcaklık derecesine ve yağış miktarına, buna karşılık daha düşük bir nispi nem değerine sahip olmuştur. Bu sonuçlara göre 2015 yılının bitki gelişimi açısından daha uygun bir yıl olduğu söylenebilir.

Araştırma sahasının toprak özelliklerini ortaya koymak için farklı noktalardan $0-30 \mathrm{~cm}$ derinliğinde toprak örnekleri alınmış ve örnekler Atatürk Üniversitesi Toprak Bilimi ve Bitki Besleme Laboratuvarında analiz edilmiştir. Yapılan analiz sonuçlarına göre deneme sahası topraklarının killi-tınlı yapıda, pH, EC (elektriksel iletkenlik), DSY (değişebilir sodyum yüzdesi), organik madde, tuz, kireç, fosfor ve potasyum değerlerinin ise sırasıyla $8.88,22.59 \mathrm{mS}$ $\mathrm{cm}^{-1}, \% 42.9, \% 0.85, \% 1.8, \% 11.75,2.04 \mathrm{~kg} \mathrm{da}^{-1}$ ve 1.95 me $100^{-1} \mathrm{~g}+65$ olduğu saptanmıştır. Bu verilere göre araştırma sahası toprakların tuzlu-alkali yapıda olduğu görülmüştür (Kacar 1986).

Araştırmada Aeluropus littoralis ve Puccinellia distans türleri bitki materyali olarak kullanılmış, fenolojik dönem olarak da vejetatif gelişme dönemi (çiçek salkımlarının oluştuğu ancak çiçeklenmenin başlamadığı dönem), çiçeklenme dönemi (bitkilerdeki salkımların \%90'nın çiçeklendiği dönem) ve tohum olgunlaştırma dönemleri (salkımdaki tüm tohumların sarardığı dönem) deneme materyali olarak yer almıştır. Araştırma korunan 4 dekarlık bir alan üzerinde tesadüf bloklarında bölünmüş parseller deneme desenine göre 3 tekerrürlü olarak kurulmuştur. Denemede ana parsellerde türler, alt parsellerde de fenolojik dönemler yer almıştır. Bitki örnekleri her iki yılda da vejetatif gelişme dönemi için Mayıs ayının son haftasında, çiçeklenme dönemi için Haziran ayının son haftasında ve tohum olgunlaştırma dönemi için de Ağustos ayının ilk haftasında alınmıştır. Bitkiler toprak seviyesinden biçilmiş ve biçilen bitki örnekleri $65{ }^{\circ} \mathrm{C}^{\prime}$ ye ayarlı kurutma fırınında ağırlıkları sabit oluncaya kadar kurutulmuştur. Daha sonra kuruyan örnekler 1 mm'lik çapa sahip elekten geçecek şekilde ot değirmeninde öğütülmüş ve kalite analizleri için hazır hale getirilmiştir. Bitki örneklerinin $\mathrm{N}$ içeriği Kjeldahl Methodu ile belirlenmiş (AOAC 1997) ve belirlenen \%N içeriği 6.25 katsayısı ile çarpılarak yem örneklerin ham protein (HP) içeriği hesaplanmıştır. Yem örneklerinin asit çözücülerde çözünemeyen lif (ADF) ve nötr çözücülerde çözünemeyen lif (NDF) oranları Van Soest et al. (1991) tarafından geliştirilen metotla belirlenmiştir. Örneklerin kuru madde sindirilebilirlikleri (KMS), Sheaffer et al. (1995) tarafından geliştirilen formül kullanılarak tahmin edilmiştir (\%KMS = 88.9 - (0.779 x \%ADF). Sonra KMS değerleri, Fonnesbeck et al. (1984) tarafından geliştirilen regresyon denklemi kullanılarak yemlerin sindirilebilir enerji (SE) oranları saptanmıştır (SE $=0.27$ $+0.0428 \times$ \%KMS). Daha sonra SE değerleri Khalil et al. (1986) tarafından geliştirilen eşitlik (Mcal kg ${ }^{-1}=0.821$ x SE (Mcal $\left.\mathrm{kg}^{-1}\right)$ ) kullanılarak metabolik enerji (ME) içeriği belirlenmişir. Sonrasında ise Sheaffer et al. (1995) tarafından geliştirilen eşitlikler kullanılarak, önce kuru madde tüketimi (KMT = 120/\% NDF), sonra da nispi yem değerleri (NYD) hesaplanmıştır (NYD = KMS x KMT/1.29).

Araştırma sonucunda elde edilen veriler JMP 5.1 istatistik paket programı kullanılarak iki yıl tekrarlanan bölünmüş parseller deneme desenine göre varyans analizine tabi tutulmuş ve önemli çıkan ortalamaların karşılaştırılması LSD testine göre yapılmıştır.

Çizelge 1. Araştırmanın yürütüldüğü Iğdır ilinin 2015 ve 2016 ile uzun yıllar (1960-2014) ortalamasına ait iklim değerleri^ Table 1. Some meteorological data of Igdır province for the experimental years and as long term average (1960-2014)*

\begin{tabular}{|c|c|c|c|c|c|c|c|c|c|}
\hline \multirow{2}{*}{ Aylar } & \multicolumn{3}{|c|}{ Ortalama Sıcaklık ( $\left.{ }^{\circ} \mathrm{C}\right)$} & \multicolumn{3}{|c|}{ Toplam Yağış (mm) } & \multicolumn{3}{|c|}{ Nispi Nem (\%) } \\
\hline & UYO** & 2015 & 2016 & UYO** & 2015 & 2016 & UYO** & 2015 & 2016 \\
\hline Ocak & -3.1 & 1.2 & -1.3 & 13.6 & 2.2 & 24.7 & 64.5 & 63.3 & 68.2 \\
\hline Şubat & 0.4 & 4.3 & 4.6 & 14.9 & 4.4 & 6.2 & 57.0 & 59.5 & 63.7 \\
\hline Mart & 7.3 & 8.5 & 9.2 & 20.5 & 52 & 10 & 46.2 & 50.8 & 48.7 \\
\hline Nisan & 13.6 & 13.8 & 14.5 & 44.3 & 44.1 & 20.1 & 47.1 & 47.7 & 48.4 \\
\hline Mayıs & 18.0 & 18.3 & 18.5 & 50.6 & 41.5 & 23.5 & 48.5 & 52.9 & 55.3 \\
\hline Haziran & 22.9 & 25.1 & 22.6 & 31.8 & 27.8 & 25.7 & 42.3 & 40 & 51.1 \\
\hline Temmuz & 26.5 & 28.7 & 26 & 15.1 & 0.3 & 22 & 39.9 & 33.6 & 47.9 \\
\hline Ağustos & 26.5 & 27.2 & 27.2 & 9.4 & 14.3 & 4.1 & 40.5 & 40.7 & 45.3 \\
\hline Eylül & 20.7 & 22.6 & 20.4 & 12.8 & 1.4 & 5.9 & 46.5 & 43.6 & 49.9 \\
\hline Ekim & 13.7 & 16.6 & 12.5 & 22.0 & 96.2 & 12.9 & 59.2 & 71.3 & 69 \\
\hline Kasım & 5.7 & 9.2 & 3.7 & 16.8 & 4.5 & 17.3 & 61.9 & 66 & 70.5 \\
\hline Aralık & -0.6 & 1.5 & -3.8 & 11.9 & 13.7 & 35.1 & 67.0 & 68.8 & 69.8 \\
\hline Ort./Top. & 12.6 & 14.8 & 12.8 & 263.8 & 302.4 & 207.5 & 51.7 & 53.2 & 57.3 \\
\hline
\end{tabular}

*MGM, 2016; **Uzun yıllar ortalaması 
Temel, Tuzlu-Alkali Meralarda Yaygın Olarak Yetişen Çorak Çimi (Puccinellia distans) ve Sahil Ayrığı (Aeluropus littoralis) Bitkilerinin Farklı Gelişme Dönemlerindeki Besin İçeriklerinin Belirlenmesi

\section{BULGULAR VE TARTIŞMA}

Yapılan istatistik analizler sonucu interaksiyonların önemli çıktığı parametrelerde (HP oranı) ana faktörler üzerinde ayrı ayrı durulmamış, ikili interaksiyonlara göre veri sunumu ve tartışması yapılmıştır. İnteraksiyonlarının önemsiz çıktığı parametrelerde ise ana faktörler dikkate alınarak yorumlamaya gidilmiştir. Yemin gerçek protein değerini vermeyen ancak organik maddeler içerisinde nitrojen içeren tüm maddeleri kapsayan ham protein (HP) içeriği, yemin kalitesini ortaya koyan önemli bir parametredir (Ball et al., 2001). Yürütülen bu çalışmada ham protein oranı üzerine tür $x$ gelişme dönemi interaksiyonunun etkisi \%1 ihtimal seviyesinde önemli bulunmuştur (Şekil 1). Şekil 1 incelendiğinde her iki türde de gelişme dönemlerinin ilerlemesiyle HP oranlarının azaldığı görülmüş ve $A$. littoralis türü gelişme dönemlerine göre $P$. distans türüne göre daha yüksek bir HP içeriğine sahip olmuştur. Buna göre en yüksek HP oranı \%14.83 ile vejetatif dönemde örneklemesi yapılan $A$. littoralis türünde belirlenmiştir (Şekil 1). Nitekim vejetatif ve tohum olgunlaştırma dönemlerinde hasat edilen çok sayıdaki halofit türlerde olgunlaşma (tohum olgunlaştırma döneminde) ile birlikte HP oranlarının azaldığı ifade edilmiştir (Arzani et al., 2008; Asaadi and Dadkhah 2010; Temel 2015). Ayrıca Rad et al. (2013) yürüttükleri bir çalışmada en yüksek ham protein içeriğinin (\%13.21) vejetatif dönemde toplanan $A$. littoralis türünde, başka bir araştırmacı ise en düşük ham protein oranının (\%4.0) tohum olgunlaştırma döneminde hasat edilen $P$. distans türünde ölçüldüğünü rapor etmiş (Hossaini 2004) ve bu bulgular bizim sonuçlarımızla paralellik göstermiştir. Mevcut sonuçlar dikkate alındığında A. littoralis türü her üç fenolojik dönemde de ruminantların yaşama payı için gereksinim duyulan protein ihtiyacını sağlayabilirken, $P$. distans türü vejetatif ve çiçeklenme döneminde bu gereksinimi karşılayabildiği görülmüştür. Çünkü \%8.0 ham proteinden daha az protein içeren yemlerin optimum performans için rumen mikro-organizmaları tarafından gereksinim duyulan minimum amonyak seviyelerini sağlayamadığından yetersiz olduğu düşünülmektedir (Norton 2003).

Farklı fenolojik dönemde hasat edilen türlerin ham protein içeriği üzerine gelişme dönemi $x$ yıl interaksiyonun etkileri önemli bulunmuş ve ortalama değerler Şekil 2'de yer almıştır. Doğru açıklama: vejetatif gelişme döneminde bitkilerin HPO ortalaması yıllara bağlı olarak önemli derecede değişmesine ve 2016 yılında 2015 yılına göre önemli derecede daha yüksek olmasına karşılık, diğer gelişme dönemlerinde HPO ortalaması yıllara bağlı olarak önemli bir farklılık göstermemiştir.

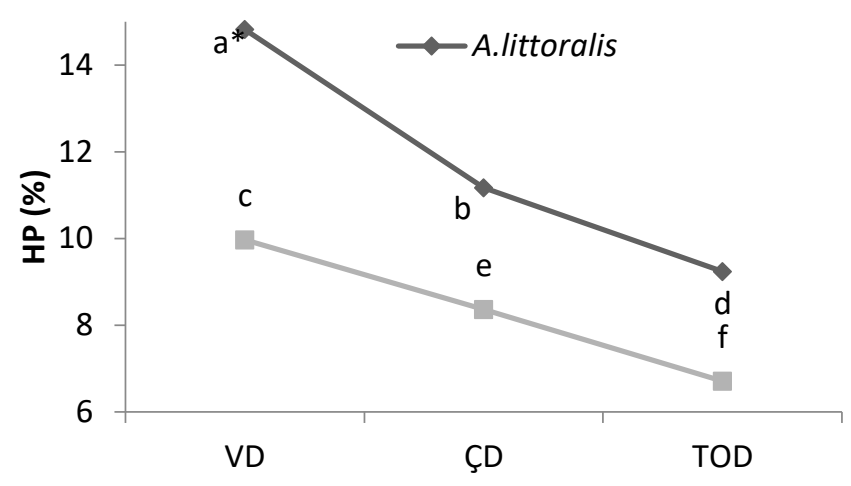

Şekil 1. HP (\%) üzerine tür $x$ gelişme dönemi interaksiyonunun etkileri.

Figure 1. The effects of speciesxstage interaction on the $C P$ (\%).

*Aynı harfl ile gösterilen HP ortalamaları $P \leq 0.01$ hata sınıları içinde LSD testine göre istatistiksel olarak farksızdır. VD: Vejetatif dönem, TOD: Tohum olgunlaştırma dönemi, ÇD: Çiçeklenme dönemi.

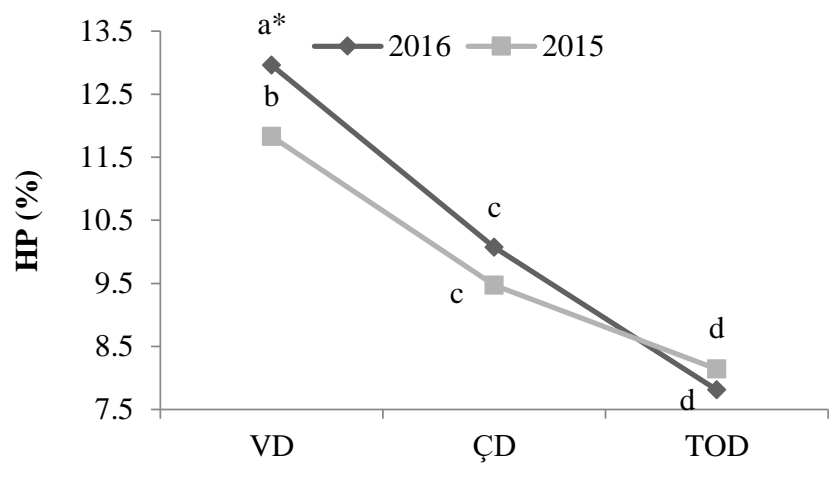

Şekil 2. HP (\%) üzerine yıl $x$ gelişme dönemi interaksiyonunun etkileri.

Figure 2. The effects of yearxstage interaction on the HP (\%). *Aynı harfl ile gösterilen HP ortalamaları $P \leq 0.01$ hata sınıları içinde LSD testine göre istatistiksel olarak farksızdır VD: Vejetatif dönem, TOD: Tohum olgunlaştırma dönemi, ÇD: Çiçeklenme dönemi

Yemin hacmi veya kabalığı hakkında fikir veren nötr çözücülerde çözünmeyen lif (NDF) oranı, hayvanlar tarafından tüketilecek yem miktarını belirleyen iyi bir ölçüdür. Dolayısıyla bir yemin NDF değeri ne kadar yüksek ise o yem, hayvanın midesinde (sindirim sisteminde) daha fazla yer kaplamakta, bu da hayvanın yem tüketimini sınırlamaktadır. Sonuçta ise NDF oranının yüksekliği hayvanın daha az protein ve enerji tüketmesine neden olmaktadır. Asit çözücülerde çözünmeyen lif (ADF) oranı ise yemin sindirilebilirliği ve hayvanın enerji alımı hakkında fikir veren iyi bir göstergedir. Başka bir ifade ile ADF oranı, en az sindirilebilir bitki karbonhidratlarının (selüloz ve lignin) bir ölçüsü olup, sindirilebilirlikle negatif bir ilişkisi vardır. 
Temel, Tuzlu-Alkali Meralarda Yaygın Olarak Yetişen Çorak Çimi (Puccinellia distans) ve Sahil Ayrığı (Aeluropus littoralis) Bitkilerinin Farklı Gelişme Dönemlerindeki Besin İçeriklerinin Belirlenmesi

Sonuç olarak ADF içeriği yemin enerji içeriğinin hesaplanmasında sıklıkla kullanılan bir kalite parametresidir. Yıllara göre iki halofit türün üç farklı fenolojik dönemde sahip oldukları ortalama NDF içerikleri Çizelge 2'de, ADF oranları ise Çizelge 3'de sunulmuştur. Yıllar arasında NDF ve ADF içerikleri istatistiki olarak önemli bulunmuş ve her iki parametre açısından 2016 yılı 2015 yılına göre daha düşük bir değere sahip olmuştur. Yıllar arasında oluşan bu farklıık iklim koşullarından kaynaklanmış olabilir. Nitekim Çizelge 1 incelendiğinde 2015 yılı 2016 yılına göre daha yağışı, bitki gelişimi açısından sıcaklık ve nispi nem koşulları daha uygun geçmiştir. Bu da bitkilerin daha fazla boylanmasına, sap/yaprak oranının artmasına ve daha fazla yapısal karbonhidratların oluşmasına neden olduğu düşülmektedir. Farklı halofit ve kserofit yem bitkisi türleri ile yürütülen çalışmalarda da, yağış ve sıcaklık değerlerinin yüksek olduğu yıllarda veya dönemlerde NDF ve ADF gibi değerlerin yüksek olduğu ortaya konmuştur (Temel et al., 2015).

ADF içeriği açısından türler arasında önemli bir değişim görülürken $(P<0.01)$ (Çizelge 3$)$, NDF içeriği açısından önemli bir farklılık bulunmamıştır (Çizelge 2). $P$. distans türünün kuru maddesindeki $A D F$ içeriğinin $A$. littoralis türüne göre istatistiksel olarak önemli derecede daha yüksek olduğu ortaya çıkmıştır. Türlerin sahip oldukları genetik ve morfolojik yapı farklııkları ADF oranlarının farklılık göstermesine neden olmuş olabilir. Çünkü $P$. distans, A. littoralis türüne göre daha fazla boylanma ve sap oluşturmaktadır. Farklı ekolojilerde yürütülen çalışmalarda da ADF oranının halofit türler arasında farklılık gösterdiği ortaya konulmuş (Rad et al., 2013; Ahmadi et al., 2015; Temel 2015; Temel et al., 2015) ve bu sonuçlar bizim bulgularımızla paralellik göstermiştir. NDF ve ADF içeriği açısından gelişme dönemleri arasındaki farklılıklar istatistiki olarak önemli bulunmuş ve vejetatif gelişme döneminde diğer iki fenolojik döneme göre bitkilerin kuru maddelerinin daha düşük NDF ve ADF içeriğine sahip olduğu ortaya çıkmıştır. Başka bir ifade ile bitkilerde gelişme dönemlerinin ilerlemesiyle NDF ve ADF değerlerinde önemli artışların olduğu saptanmıştır (Çizelge 2 ve 3).

Çizelge 2. Türlere ve gelişme dönemlerine göre $A$. littoralis ve $P$. distans türlerinin NDF içeriği (\%).

Table 2. The NDF contents (\%) of A. littoralis and P. distans at different development stages in the years of 2015 and 2016.

\begin{tabular}{llcccc}
\hline \multirow{2}{*}{ Yıllar } & \multirow{2}{*}{ Türler } & \multicolumn{3}{c}{ Fenolojik dönemler } & \multirow{2}{*}{ Yılların ortalaması } \\
\cline { 3 - 4 } & & VD & ÇD & TOD & \\
\hline \multirow{2}{*}{2015} & Aeluropus littoralis & 64.77 & 68.01 & 71.61 & \multirow{2}{*}{$68.04 \mathrm{a}^{*}$} \\
& Puccinellia distans & 64.50 & 68.59 & 70.78 & \\
& Aeluropus littoralis & 63.10 & 66.01 & 69.01 & \multirow{2}{*}{$65.84 \mathrm{~b}$} \\
\hline Dönemlerin ortalaması & Puccinellia distans & 61.93 & 66.45 & 68.56 & \\
\hline \multirow{2}{*}{ Türlerin ortalaması } & Aeluropus littoralis & $63.58 \mathrm{c}^{*}$ & $67.26 \mathrm{~b}$ & $69.99 \mathrm{a}$ & \\
& Puccinellia distans & 67.09 & & & \\
\hline LSD $(0.05)$ & 66.80 & & &
\end{tabular}

*Aynı sütun ve satırda benzer harf ile gösterilen ortalamalar LSD testine göre $\mathrm{P} \leq 0.01$ hata sınırları içerisinde istatistiksel olarak birbirinden farksızdır. ${ }^{* \star} P<0.01$ seviyesinde önemlidir. VD: Vejetatif dönem, TOD: Tohum olgunlaştırma dönemi, ÇD: Çiçeklenme dönemi.

Çizelge 3. Türlere ve gelişme dönemlerine göre $A$. littoralis ve $P$. distans türlerinin ADF içeriği (\%).

Table 3. The ADF contents (\%) of A. littoralis and P. distans at different development stages in the years of 2015 and 2016.

\begin{tabular}{|c|c|c|c|c|c|}
\hline \multirow{2}{*}{ Yıllar } & \multirow{2}{*}{ Türler } & \multicolumn{3}{|c|}{ Fenolojik dönemler } & \multirow{2}{*}{-Yılların ortalaması } \\
\hline & & VD & ÇD & TOD & \\
\hline \multirow{2}{*}{2015} & Aeluropus littoralis & 33.6 & 36.52 & 38.64 & \multirow{2}{*}{$37.07 a^{*}$} \\
\hline & Puccinellia distans & 34.3 & 36.78 & 42.61 & \\
\hline \multirow[b]{2}{*}{2016} & Aeluropus littoralis & 30.33 & 34.37 & 36.39 & \multirow[b]{2}{*}{$34.80 \mathrm{~b}$} \\
\hline & Puccinellia distans & 33.03 & 36.14 & 38.53 & \\
\hline \multicolumn{2}{|c|}{ Dönemlerin ortalaması } & $32.81 c^{*}$ & $35.95 \mathrm{~b}$ & $39.04 a$ & \\
\hline \multirow{2}{*}{ Türlerin ortalaması } & Aeluropus littoralis & $34.98 b^{*}$ & & & \\
\hline & Puccinellia distans & $36.90 \mathrm{a}$ & & & \\
\hline
\end{tabular}

${ }^{\star}$ Aynı sütun ve satırda benzer harf ile gösterilen ortalamalar LSD testine göre $P \leq 0.01$ hata sınıları içerisinde istatistiksel olarak birbirinden farksızdır. ${ }^{\star *} \mathrm{P}<0.01$ seviyesinde önemlidir. VD: Vejetatif dönem, TOD: Tohum olgunlaştırma dönemi, ÇD: Çiçeklenme dönemi. 
Temel, Tuzlu-Alkali Meralarda Yaygın Olarak Yetişen Çorak Çimi (Puccinellia distans) ve Sahil Ayrığı (Aeluropus littoralis) Bitkilerinin Farklı Gelişme Dönemlerindeki Besin İçeriklerinin Belirlenmesi

Konu ile ilgili olarak Rad et al. (2013) A. littoralis türü ile yürüttükleri bir çalışmada en düşük $A D F$ oranını (\%35.0) vejetatif dönemde yapılan hasattan, Yousef Elahi (2013) ise en yüksek NDF içeriğinin (\%66.90) sonbahar döneminde (tohum olgunlaştırma) yapılan biçimden elde ettiklerini ifade etmişler ve bu sonuçlar bizim bulgularımızla benzerlik göstermiş̧ir. Ayrıca Panahi et al. (2012), üç soda otu (Salsola sp) türünde NDF ve ADF içeriklerinin büyüme döneminin ilerlemesiyle artığını rapor etmişlerdir. Yine halofit türlerle yürütülen çalışmalarda bitkilerin olgunlaşmasıyla ADF ve NDF oranlarının arttığı ortaya konulmuştur (Asaadi and Dadkhah 2010). Oluşan bu farklılıklar olgunlaşma ile birlikte bitki bünyesindeki lifli bileşiklerin oranının artmasından kaynaklanmaktadır. Çünkü genç bitki hücreleri primer hücre duvarı olan tek bir katmana sahipken, bitkiler olgunlaştıkça ikinci bir hücre duvarı daha oluşmakta ve bu hücre duvarında ise selüloz, hemiselüloz ve lignin gibi yapısal karbonhidratlar daha yoğun bir şekilde bulunmaktadır (Asaadi and Yazdi 2011; Martiniello and Teixeira da Silva 2011). Nitekim halofitlerde olgunlaşmanın ilerlemesiyle selüloz, hemiselüloz, lignin ve silika gibi hücre duvarı bileşenlerinin arttığı rapor edilmiştir (Arzani et al., 2006). Kuru madde sindirilebilirliği (KMS), ADF değeri kullanılarak hesaplanmakta ve daha düşük ADF içeriği daha yüksek sindirilebilirliği göstermektedir. Metabolik enerji (ME) içeriği ise dışkı, idrar veya rumen gazı ile kaybolmayan yemdeki enerjiyi belirlemektedir (Ball et al., 2001). Varyans analiz sonuçları KMS, sindirilebilir enerji (SE) ve ME içeriklerinin türler, gelişme dönemleri ve yıllar arasında önemli farklılıklar gösterdiğini ortaya koymuştur (Çizelge 4, 5 ve 6).

İki tür arasında $A$. littoralis türünün $\mathrm{KMS}$, SE ve ME içeriği ortalamalarının $P$. distans türüne göre istatistiksel olarak önemli derecede daha yüksek olduğu ortaya çıkmıştır (Çizelge 4, 5 ve 6). Bu durum, türlerin sahip oldukları genetik ve morfolojik yapı farklıı̆ından kaynaklanmış olabilir. Yapılan gözlemler ve araştırmalar sonucu rizom habitus formuna sahip $A$. littoralis türünün yumak formuna sahip $P$. distans türüne göre hem daha kısa boylu hem de bitki taç kısmında daha fazla yapraklıık bulundurduğu görülmüştür. Bu da, A. littoralis türünde yaprak/sap oranının daha yüksek olmasına neden olmuş olabilir. Çünkü yapraklar saplara göre sindirilebilirliği zor olan daha az hücre duvarı maddelerini (selüloz, hemiselüloz ve lignin) ve daha fazla hücre içi maddelerini (protein, nişasta, şeker ve yağ) içermektedir (Nelson and Moser 1994). Dolayısıyla bu durum $A$. littoralis türünün $P$. distans türüne göre daha yüksek sindirilebilirliğe ve enerji içeriğine sahip olmasına neden olmuş olabilir.

Çizelge 4. Türlere ve gelişme dönemlerine göre $A$. littoralis ve $P$. distans türlerinin KMS (\%).

Table 4. DDM ratios (\%) of A. littoralis and P. distans at different development stages in the years of 2015 and 2016.

\begin{tabular}{llcccc}
\hline \multirow{2}{*}{ Yıllar } & \multirow{2}{*}{ Türler } & \multicolumn{3}{c}{ Fenolojik dönemler } & \multirow{2}{*}{ Yılların ortalaması } \\
\cline { 3 - 5 } 2015 & & VD & ÇD & TOD & \\
& Aeluropus littoralis & 62.73 & 60.45 & 58.80 & \multirow{2}{*}{$60.02 \mathrm{~b}^{*}$} \\
& Puccinellia distans & 62.18 & 60.25 & 55.71 & \\
& Aeluropus littoralis & 65.28 & 62.12 & 60.56 & \multirow{2}{*}{$61.79 \mathrm{a}$} \\
\hline \multirow{2}{*}{ Dönemlerin ortalaması } & Puccinellia distans & 63.17 & 60.75 & 58.89 & \\
\hline \multirow{2}{*}{ Türlerin ortalaması } & Aeluropus littoralis & $63.34 \mathrm{a}^{*}$ & $60.89 \mathrm{~b}$ & $58.49 \mathrm{c}$ & \\
& Puccinellia distans & $61.66 \mathrm{a}^{*}$ & & & \\
\hline LSD & $60.16 \mathrm{~b}$ & & & \\
& Dönem: 1.07* & & & &
\end{tabular}

${ }^{\star}$ Aynı sütun ve satırda benzer harf ile gösterilen ortalamalar LSD testine göre $P \leq 0.01$ hata sınırları içerisinde istatistiksel olarak birbirinden farksızdır. ${ }^{* *} \mathrm{P}<0.01$ seviyesinde önemlidir. VD: Vejetatif dönem, TOD: Tohum olgunlaştırma dönemi, ÇD: Çiçeklenme dönemi.

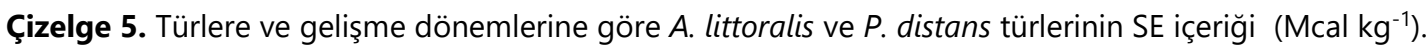

Table 5. DE contents (Mcal kg-1). of A. littoralis and P. distans at different development stages in the years of 2015 and 2016.

\begin{tabular}{|c|c|c|c|c|c|}
\hline \multirow{2}{*}{ Yıllar } & \multirow{2}{*}{ Türler } & \multicolumn{3}{|c|}{ Fenolojik dönemler } & \multirow{2}{*}{ Yılların ortalaması } \\
\hline & & VD & ÇD & TOD & \\
\hline \multirow{2}{*}{2015} & Aeluropus littoralis & 2.96 & 2.86 & 2.78 & \multirow{2}{*}{$2.84 b^{*}$} \\
\hline & Puccinellia distans & 2.93 & 2.85 & 2.65 & \\
\hline \multirow{2}{*}{2016} & Aeluropus littoralis & 3.06 & 2.93 & 2.86 & \multirow{2}{*}{$2.91 \mathrm{a}$} \\
\hline & Puccinellia distans & 2.97 & 2.87 & 2.79 & \\
\hline Dönemlerin ortalaması & & $2.98 a^{*}$ & $2.88 \mathrm{~b}$ & $2.77 \mathrm{c}$ & \\
\hline \multirow{2}{*}{ Türlerin ortalaması } & Aeluropus littoralis & $2.91 a^{*}$ & & & \\
\hline & Puccinellia distans & $2.85 \mathrm{~b}$ & & & \\
\hline $\operatorname{LSD}_{(0.05)}$ & Dönem: $0.04^{\star \star}$ & & & & \\
\hline
\end{tabular}

*Aynı sütun ve satırda benzer harf ile gösterilen ortalamalar LSD testine göre $\mathrm{P} \leq 0.01$ hata sınırları içerisinde istatistiksel olarak birbirinden farksızdır. ${ }^{* *} \mathrm{P}<0.01$ seviyesinde önemlidir. VD: Vejetatif dönem, TOD: Tohum olgunlaştırma dönemi, ÇD: Çiçeklenme dönemi. 
Temel, Tuzlu-Alkali Meralarda Yaygın Olarak Yetişen Çorak Çimi (Puccinellia distans) ve Sahil Ayrığı (Aeluropus littoralis) Bitkilerinin Farklı Gelişme Dönemlerindeki Besin İçeriklerinin Belirlenmesi

Konu ile ilgili olarak Negus (1982), P. distans'ın yaklaşık $\% 50$ sindirilebilirliğe sahip olduğunu ifade etmiş ve bu sonuçlar bizim bulgularımızı destekler niteliktedir. Ayrıca farklı ekolojilerde yürütülen çalışmalarda halofit türler arasında KMS, SE ve ME değerlerinin farklılık gösterdiği ortaya konulmuştur (Rad et al., 2013; Ahmadi et al., 2015).

Gelişme dönemleri arasında en yüksek değerler vejetatif gelişme döneminde belirlenmiş ve olgunlaşma döneminin ilerlemesiyle KMS, SE ve ME değerlerinde düşüşler görülmüştür (Çizelge 4, 5 ve 6). Gelişme döneminin ilerlemesiyle KMS, SE ve ME değerlerindeki azalma muhtemelen bitki bünyesindeki yapısal karbonhidratların yapısal olmayan karbonhidratlara olan oranındaki artıştan kaynaklanmış olabilir. Çünkü olgunlaşma ile birlikte bitki bünyesinde lifli bileşiklerin oranında önemli artışlar olmakta, bu da bitkilerin sindirilebilirliğini ve enerji içeriğini düşürmektedir. Nitekim Rad et al. (2013) yem kalitesi ve besin değerindeki artışın bitkilerdeki HP, KMS ve ME içeriği ile pozitif, ADF ve ham lif içeriği ile de negatif ve doğrusal bir ilişki içinde olduğunu rapor etmişlerdir. Konu ile ilgili olarak Arzani et al. (2004), bitkilerin olgunlaşmasıyla KMS, SE ve ME içeriklerinin azalmasının saplardaki yapısal dokuların artmasından kaynaklandığını ifade etmişlerdir. Ayrıca halofit türlerle yürütülen çalışmalarda bitki büyüme döneminin ilerlemesiyle selüloz, hemiselüloz ve lignin gibi yapısal karbonhidratların arttığı, yemlerin sindirilebilirliği, ME ve SE içeriğinin ise azaldığı rapor edilmiş (McDonald et al., 1995; Arzani et al., 2006; Asaadi and Dadkhah 2010; El-Shaer 2010; Esfahan et al., 2010; Panahi et al., 2012; Ahmadi et al., 2015, Temel 2015; Temel et al., 2015) ve bu bulgular bizim sonuçlarımızı destekler niteliktedir. Dolayısıyla bitkilerin olgunlaşması ve olgunlaşma ile birlikte yapısal karbonhidratlardaki artış yemde daha yüksek lifli bileşiklerin bulunmasına ve daha az oranda KMS,
SE ve ME içeriğine sahip olmasına neden olabilmektedir.

Yıllara göre KMS, SE ve ME değerleri sırasıyla Çizelge 4, 5 ve 6'da görülmektedir. Her üç özellik için ortalama değerler 2016 yılında 2015 yılına göre istatiksel olarak daha yüksek olmuştur. Yıllar arasında oluşan bu farklıı̆ın iklim koşullarından kaynaklandığı düşünülmektedir. Çizelge $1^{\prime}$ de görüldüğü üzere çalışmanın yürütüldüğü 2015 yılı, 2016 yılına göre göre daha fazla miktarda yağış almış ve daha yüksek sıcaklık derecesine sahip olmuştur. Bu da 2015 yılında bitkilerin 2016 yılına göre daha fazla bir boylanma ve daha gümrah bir gelişme göstermesine neden olmuştur. Daha fazla bir boylanma ve gümrah gelişme ise bitki bünyesinde yapısal karbonhidratlar olan lifli bileşiklerin oranında artışlara neden olmuş olabilir. Çünkü yapısal karbonhidratlar yemlerin sindirilebilirliğini, ME ve SE içeriğini önemli oranda azaltmaktadır (McDonald et al., 1995; Arzani et al., 2006; Asaadi and Dadkhah 2010; El-Shaer 2010; Esfahan et al., 2010; Panahi et al., 2012; Ahmadi et al., 2015).

Mevcut çalışmada nispi yem değeri (NYD) üzerine türlerin, gelişme dönemlerin ve yılların etkisi istatistiksel olarak önemli bulunmuştur (Çizelge 7).

Çizelge 7 incelendiğinde; A. littoralis türünün $P$. distans türüne göre istartistiksel olarak önemli derecede daha yüksek NYD'ne sahip olduğu, 2016 yılında NYD ortalamasının 2015 yılına göre önemli derecede daha yüksek olduğu ve bitkilerin vejetatif gelişme döneminde NYD'nin diğer iki fenolojik döneme göre daha yüksek olduğu anlaşılmaktadır. Bu durumun, $A$. littoralis türünün $P$. distans türüne göre daha düşük ADF ve NDF içeriğine sahip olması, 2016 yılında NDF ve ADF ortalamasının 2015 yılına göre daha düşük olması ve vejetatif gelişme döneminde bitkilerinin NDF ve ADF içeriklerinin çiçeklenme ve tohum olgunlaştırma dönemindekine göre daha

Çizelge 6. Türlere ve gelişme dönemlerine göre $A$. littoralis ve $P$. distans türlerinin $\mathrm{ME}$ içeriği $\left(\mathrm{Mcal}_{\mathrm{kg}}{ }^{-1}\right)$.

Table 6. ME contents (Mcal kg-1) of A. littoralis and P. distans at different development stages in the years of 2015 and 2016.

\begin{tabular}{llcccc}
\hline \multirow{2}{*}{ Yıllar } & \multirow{2}{*}{ Türler } & \multicolumn{3}{c}{ Fenolojik dönemler } & \multirow{2}{*}{ Yılların ortalaması } \\
\cline { 3 - 5 } 2015 & Aeluropus littoralis & 2.42 & 2.35 & 2.29 & \multirow{2}{*}{$2.33 \mathrm{~b}^{*}$} \\
& Puccinellia distans & 2.41 & 2.34 & 2.18 & \multirow{2}{*}{$2.39 \mathrm{a}$} \\
\cline { 2 - 5 } 2016 & Aeluropus littoralis & 2.52 & 2.40 & 2.35 & \\
& Puccinellia distans & 2.44 & 2.36 & 2.29 & \\
\hline Dönemlerin ortalaması & & $2.45 \mathrm{a}^{*}$ & $2.36 \mathrm{~b}$ & $2.28 \mathrm{c}$ & \\
\hline \multirow{2}{*}{ Türlerin ortalaması } & Aeluropus littoralis & $2.38 \mathrm{a}^{*}$ & & & \\
& Puccinellia distans & $2.34 \mathrm{~b}$ & & & \\
\hline $\operatorname{LSD}_{(0.05)}$ & Dönem: 0.04** & & & & \\
\hline
\end{tabular}

*Aynı sütun ve satırda benzer harf ile gösterilen ortalamalar LSD testine göre $P \leq 0.01$ hata sınırları içerisinde istatistiksel olarak birbirinden farksızdır. ${ }^{*} \mathrm{P}<0.01$ seviyesinde önemlidir. VD: Vejetatif dönem, TOD: Tohum olgunlaştırma dönemi, ÇD: Çiçeklenme dönemi. 
Temel, Tuzlu-Alkali Meralarda Yaygın Olarak Yetişen Çorak Çimi (Puccinellia distans) ve Sahil Ayrığı (Aeluropus littoralis) Bitkilerinin Farklı Gelişme Dönemlerindeki Besin İçeriklerinin Belirlenmesi

Çizelge 7. Türlere ve gelişme dönemlerine göre $A$. littoralis ve $P$. distans türlerinin NYD.

Table 7. RFV of A. littoralis and P. distans at different development stages in the years of 2015 and 2016.

\begin{tabular}{|c|c|c|c|c|c|}
\hline \multirow{2}{*}{ Yıllar } & \multirow{2}{*}{ Türler } & \multicolumn{3}{|c|}{ Fenolojik dönemler } & \multirow{2}{*}{ Yılların ortalaması } \\
\hline & & VD & ÇD & TOD & \\
\hline \multirow{2}{*}{2015} & Aeluropus littoralis & 90.12 & 82.68 & 76.40 & \multirow{2}{*}{$82.32 b^{\star}$} \\
\hline & Puccinellia distans & 89.72 & 81.78 & 73.21 & \\
\hline \multirow{2}{*}{2016} & Aeluropus littoralis & 96.30 & 87.55 & 81.62 & \multirow{2}{*}{$87.57 \mathrm{a}$} \\
\hline & Puccinellia distans & 94.93 & 85.06 & 79.93 & \\
\hline Dönemlerin ortalaması & & $92.77 a^{*}$ & $84.27 b$ & $77.79 \mathrm{c}$ & \\
\hline \multirow{2}{*}{ Türlerin ortalaması } & Aeluropus littoralis & $85.79 \mathrm{a}^{+}$ & & & \\
\hline & Puccinellia distans & $84.11 \mathrm{~b}$ & & & \\
\hline $\operatorname{LSD}_{(0.05)}$ & Dönem: $2.82^{\star *}$ & & & & \\
\hline
\end{tabular}

*Aynı sütun ve satırda benzer harf ile gösterilen ortalamalar LSD testine göre $P \leq 0.01$ hata sınırları içerisinde istatistiksel olarak birbirinden farksızdır. +Aynı sütunda benzer harf ile gösterilen ortalamalar $P \leq 0.05$ hata sınırları içinde LSD testine göre istatistiksel olarak farksızdır. ${ }^{*} \mathrm{P}<0.01$ seviyesinde önemlidir. VD: Vejetatif dönem, TOD: Tohum olgunlaştırma dönemi, ÇD: Çiçeklenme dönemi.

düşük bir olmasından kaynaklandığı düşünülmektedir (Çizelge 2 ve 3). Çünkü NYD, yemin ADF ve NDF değerleri kullanılarak hesaplanan ve yemin kalitesini rakamsal olarak gösteren önemli bir ölçüdür. Dolayısıyla NYD'nin yüksek çıkması yemlerin NDF ve ADF içeriklerinin düşük olmasından kaynaklanmaktadır. Halofit türlerle yürütülen çalışmalarda da bitkilerin erken gelişme dönemlerinde daha yüksek bir yem kalitesine sahip olduğu oysa olgunlaşma döneminin ilerlemesiyle NYD'nin ve dolayısıyla yem kalitesinin azaldığı ortaya konmuştur (Temel 2015).

\section{SONUÇ}

Aşırı tuzlu-alkali toprak koşulları pek çok kültür bitkisinin ekonomik anlamda yetişmesini kısıtlamakta ve vejetasyonda bulunan otsu türlerin ise çok az bir kısmının yetişmesine imkan sağlamaktadır. Ancak bu gibi marjinal alanlarda $A$. littoralis ve $P$. distans türlerinin kolaylıkla yetişebildiği ve otlayan hayvanlar için orta kalitede bir yem materyali ürettiği ortaya konmuştur. Özellikle $A$. littoralis türünün incelenen kalite parametreleri açısından $P$. distans türüne kıyasla besin içeriği daha yüksek bir yem ürettiği belirlenmiştir. Mevcut araştırmada ortaya konulan diğer bir sonuç ise, incelemeye alınan her iki halofit türde de olgunlaşma döneminin ilerlemesiyle yem kalite değerlerinde düşüşlerin yaşandığı ve özellikle erken gelişme dönemlerinde yüksek yem kalitesinin elde edildiğidir. Son olarak yıllara bağlı olarak iklim özelliklerinin farklılık göstermesinin, türlerin besin içeriğinin de farklılık göstermesine neden olduğu belirlenmiştir.

\section{KAYNAKLAR}

Ahmadi A., Arzani $\mathrm{H}$ and Jafari AA., 2005. Determination and Composition of Forage Quality of Five Species in Different Phenological Stages in Alborz Rangelands. XX International Grassland Congress, 26 June-1 July, Ireland,
Ahmadi A., Gomarian M and Toranjzar H., 2015. Variations in Forage Quality of Two Halophyte Species, at Three Phenological Stages in Marginal Rangelands of Meighan Playa, Iran. International Conference on Chemical, Civil and Environmental Engineering (CCEE-2015) June 5-6, 2015 Istanbul, Turkey.

Ali Ehsani HY., Elham Shafeian MTG and Yeganeh H., 2016. Determining suitable grazing time for Puccinella distans Parl. based on its phenology in West Azerbaijan Province of Iran. Journal of Plant Interactions, 11(1): 67-73.

AOAC 1997. Official Methods of Analysis. Association of Official Analytical Chemists. $16^{\text {th }}$ ed. 3rd revision. Arlington, VA, USA.

Arzani H., Torkan J., Jafari M and Nikkah A., 2001. Investigation on effects of phenological stages and environmental factors (soil and climate) on forage quality of some important range species. Journal of Agriculture Science, 32: 385-397.

Arzani H., Zohdi M., Fish E., Amiri GZ., Nikkhah A and Wester D., 2004. Phenological effects on forage quality of five grass species. Journal of Range Management, 57: 624629.

Arzani H., Bashiri M., Khatibi F and Ghorbani G., 2006. Nutritive value of some Zagros Mountain rangeland species. Small Ruminant Research, 65: 126-135.

Arzani H., Sadeghimanesh MR., Azarnivand H., Asadian GH and Shahriyari E., 2008. Study of phenological stages effect values of twelve species in Hamadan rangelands. Iran Journal of Range Desert Research, 16(1): 86-95.

Asaadi AM and Dadkhah AR., 2010. The study of forage quality of Haloxylon aphyllum and Eurotia ceratoidesin different phenological stages. Research Journal of Biological Sciences, 5: 470-475.

Asaadi AM and Yazdi AK, 2011. Phenological stage effets on forage quality of four forbs species. Journal of Food Agriculture and Environment. 9(2): 380-384.

Ball DM., Collins M., Lacefield GD., Martin NP., Mertens DA., Olson KE., Putnam DH., Undersander DJ and Wolf MW., 2001. Understanding Forage Quality. Park Ridge, USA: American Farm Bureau Federation Publication. 
Temel, Tuzlu-Alkali Meralarda Yaygın Olarak Yetişen Çorak Çimi (Puccinellia distans) ve Sahil Ayrığı (Aeluropus littoralis) Bitkilerinin Farklı Gelişme Dönemlerindeki Besin İçeriklerinin Belirlenmesi

Brotherson JD., 1987. Plant community zonation in response to soil gradients in a saline meadow near Utah Lake, Utah County, Utah. Great Basin Natur 47: 322-333.

El Shaer HN., 1997. Sustainable utilization of halophytic plant species as livestock fodder in Egypt. Proceedings of the International Conference on Water management, salinity and pollution Control Towards Sustainable Irrigation in the Mediterranean region. 22-26 September, Bari, Italy.

El-Shaer HM., 2010. Halophytes and salt-tolerant plants as potential forage for ruminants in the Near East region. Small Ruminant Research, 91: 3-12.

Esfahan EZ., Assareh MH., Jafari M., Jafari AA., Javadi SA and Karimi G., 2010. Phenological effects on forage quality of two halophyte species Atriplex leucoclada and Suaeda vermiculata in four saline rangelands of Iran. Journal of Food, Agriculture and Environment, 8: 999-1003.

Fonnesbeck PV., Clark DH., Garret WN and Speth CF., 1984. Predicting energy utilization from alfalfa hay from the Western Region. Proceedings of the American Society of Animal Science, 35: 305-308.

Gulzar S and Khan MA., 2001. Seed germination of a halophytic grass. Aeluropus lagopoides. Annals of Botany, 87: 319-324.

Gulzar S., Khan MA and Ungar IA., 2003. Effects of salinity on growth, ionic content and plant water relations of Aeluropus lagopoides. Communications in Soil Science and Plant Analysis, 34: 1657-1668.

Hitchcock AS., 1971. Manual of the Grasses of the United States. Dover Publications, New York.

Hossaini SA., 2004. Autecology of Puccinellia distans (Jacq.) Parl. in Saline and Alkaline Habitats North Gorgan Region. Proceedings of the Fourth International Iran \& Russia Conference, 8-10 September, Iran-Shahrekord.

Hughes TD., 1972. Puccinellia distans: a salt-tolerant grass, in Illinois Turfgrass Conference, ed. by Hughes TD. Illinois Cooperative Extension Service, Champaign, IL.

Kacar B., 1986. Gübreler Gübreleme Tekniği. T.C. Ziraat Bankası Kültür Yayınları, No: 20, Ankara.

Khalil JK., Sawaya WN and Hyder SZ., 1986. Nutrient composition of Atriplex leaves grown in Saudi Arabia. Journal of Range and Management, 39: 104-107.

Martiniello P and Teixeira da Silva JA., 2011. Physiological and bioagronomical aspects involved in growth and yield componenets of cultivated forage species in Mediterranean environments: A review. European Journal of Plant Science and Biotechnology, 5(Specieal Issue 2): 64-98.

McDonald P., Edwards RA., Greenhalgh JFD and Morgan CA., 1995. Animal Nutrition. New York, USA: Longman Scientific and Technical.

MGM., 2016. Başbakanlık DMi Genel Müdürlüğü Meteroloji Bültenleri, Ankara.
Negus TR., 1982 Puccinellia, Its Grazing Value and Management. Farmnote No. 34/82. Western Australian Department Agriculture.

Nelson CJ and Moser LE., 1994. Plant Factors affecting forage quality. Forage Quality, Evaluation and Utilization (Ed. Fahey JR.), Madison: American Society of Agrononmy, pp. 115-154.

Norman HC., Dynes RA and Masters DG., 2002. Nutritive value of plants growing on saline land, in Proceedings of the 8th National Conference and Workshop on the Productive Use and Rehabilitation of Saline Lands (PURSL), 16-20 September, Fremantle, Western Australia.

Norton BW., 1982. Differences Between Species in Forage Quality. Common wealth Agricultural Bureaux, Farnham Royal, UK.

Norton BW., 2003. The nutritive value of tree legumes. Forage Tree Legumes in Tropical Agriculture (Eds. Gutteridge RC and Shelton HM), pp. 1-10.

Özdoğan N., 1976. Rüzgar Erozyonu ve Rüzgar Erozyonu Sahalarında Alınacak Başlıca Tedbirler. Topraksu Genel Müdürlüğü Yayınları, 306, Ankara.

Panahi F., Assareh MH., Jafari M., Jafari A., Arzani H., Tavili A and Zandi Esfahan E., 2012. Phenological effects on forage quality of Salsola arbuscula, Salsola orientalis and Salsola tomentosa in three habitats in the central part of Iran. Middle-East Journal of Scientific Research, 11: 800807.

Peng YH., Zhu YF., Mao YQ., Wang SM., Su WA and Tang ZC., 2004. Alkali grass resists salt stress through high $[\mathrm{K}+]$ and an endodermis barrier to $\mathrm{Na}+$. Journal of Experimental Botany, 55: 939-949.

Rad MS., Rad JS., Teixeira da Silva JA and Mohsenzadeh S., 2013. Forage quality of two halophytic species, Aeluropus lagopoides and Aeluropus littoralis, in two phenological stages. International Journal of Agronomy and Plant Production, 4: 998-1005.

Robinson PH., Grattan SR., Getachew G., Grieve CM., Poss JA., Suarez DL and Benes SE., 2004. Biomass accumulation and potential nutritive value of some forages irrigated with saline-sodic drainage water. Animal Feed Science and Technology, 111: 175-189.

Scalia R., Oddo E., Saiano F and Grisafi F., 2009. Effect of salinity on Puccinellia (L.) Parl. Treates with $\mathrm{NaCl}$ and foliarly applied glycinebetaine. Plant Stress, 3(1): 49-54.

Sheaffer CC., Peterson MA., Mccalin M., Volene JJ., Cherney JH., Johnson KD., Woodward WT and Viands DR., 1995. Acide Detergent Fiber, Neutral Detergent Fiber Concentration and Relative Feed Value. North American Alfalfa Improvemnt Conference, Minneapolis.

Shidaei G and Namati N., 1978. Modern Rangemanagement and Forage Production in Iran. Forests and Rangelands Organization, Tehran, Iran. 
Temel, Tuzlu-Alkali Meralarda Yaygın Olarak Yetişen Çorak Çimi (Puccinellia distans) ve Sahil Ayrığı (Aeluropus littoralis) Bitkilerinin Farklı Gelişme Dönemlerindeki Besin İçeriklerinin Belirlenmesi

Squires VR and Ayoub AT., 1994. Halophytes as a Resurce for Livestock and for Rehabilitation of Degraded Lands. Kluwer Academic Publisher, Dordrecht Boston, London, UK.

Tarasoff CS., Mallory-Smith CA and Ball DA., 2007. Comparative plant responses of Puccinellia distans and Puccinellia nuttalliana to sodic versus normal soil types. Journal of Arid Environments, 70: 403-417.

Temel S., 2015. Determination of fodder quality parameters in vegetative and seed maturity stages of Salsola tragus L. and Noaea mucronata (Forssk.) Asch. \& Schweinf. International Journal of Agriculture and Wildlife Science, 1: $23-30$.

Temel S., Sürmen M and Tan M., 2015. Effects of growth stages on the nutritive value of specific halophyte species in saline grasslands. Journal of Animal and Plant Science, 25: 1419-1428.

Temel S ve Şimşek U., 2011. Iğdır Ovası toprakların çoraklaşma süreci ve çözüm önerileri. Alınteri, 21(B): 5359.
Valipoor Dastenai M., Mirhadi MJ and Mehrani A., 2012. The study and comparison of 3 foxtail millet (Setaria italica L.) cultivars in different phenological stages in Karaj Region. The Journal of Applied Science and Engineering Technology, 2(3): 62-68.

Van Soest PJ., Robertson JD and Lewis BA., 1991. Methods for diatery fibre, neutral detergent fibre and non-starch polysaccharides in relation to animals nutrition. Journal of Dairy Science, 74: 3583-3597.

Warren BE., Casson T and Ryall DH., 1994. Production from grazing sheep on revegetated saltland in Western Australia. Halophytes as a Resource for Livestock and for Rehabilitation of Degraded Lands (Eds. Squires VR and Ayoub, AT), Kluwer Academic Publishers, Dordrecht, pp. 263-265.

Yousef Elahi M., 2013. Determination of nutritive value of five species of halophyte plants used by camel in East South Iran. International Research Journal of Applied and Basic Sciences, 4(9): 2721-2725. 